\title{
Assessment of Compatibility of Trichoderma Species with Different Fungicides in vitro
}

\author{
Ashish Shrivastava* \\ Department of Plant Pathology, College of Agriculture, Ganj Basoda (Vidisha), \\ Madhya Pradesh, India \\ *Corresponding author
}

\section{Keywords}

Trichoderma sps, antagonistic activity, Fungicides

Article Info

Accepted: 20 January 2019 Available Online: 10 February 2019

\section{A B S T R A C T}

The test organism Trichoderma was isolated from the soil using Trichoderma selective medium, observations for radial growth, colony characters and pigmentation were recorded on potato dextrose agar medium. For assessing the compatibility of Trichoderma species, eight fungicides (carbendazim, carboxin, triadimefon, thiophanate methyl, chlorothalonil, copper- oxychloride, mancozeb, and wettable sulphur) were used each at three concentrations 500, 1000 and $1500 \mathrm{ppm}$, respectively in addition to control and poisoned food techniques was followed in vitro. All the fungicides significantly reduce the radial growth of $T$. viride and $T$. harzianum except wettable sulphur and mancozeb. There was no radial growth of $T$. viride and $T$. harzianum in carbendazim, carboxin and thiophanate methyl, while maximum mean radial growth of $T$. viride $(85.22 \mathrm{~mm})$ and $T$. harzianum $(79.77 \mathrm{~mm})$ were recorded in wettable sulphur and mancozeb. All the three concentrations significantly reduced the radial growth of $41.15 \mathrm{~mm}$ in $T$. viride and 34.66 $\mathrm{mm}$ in $T$. harzianum being maximum in $1500 \mathrm{ppm}$. The significant interaction component clearly revealed that with increasing concentration of each fungicide, there was a significant reduction in radial growth.

\section{Introduction}

The present agricultural scenario signifies the importance of IDM strategies in crop protection. Therefore a through know-how of the bio-control status involving mechanism of action, spectrum of activity, efficiency of the bio-agent and effect of concerned microenvironment on its growth and survival is very essential. Trichoderma is one of the most potent bio-control agent used nowadays majority for seed and soil treatment due to its efficient antagonistic activity against various soil and seed borne pathogens. Application of the concerned antagonist is easy, economically feasible, saves time and money besides reducing the amount of agrochemicals required to control a disease at field level both at pre and post infection stages. Fungicides are applied to the field as both soil drenches and foliar sprays. Besides, agrochemicals sprayed aerially reach the soil by means of air currents or are washed off the plant surface due to rain. Thus, there is a need 
to determine the compatibility of the bioagents in presence of commonly used fungicides to obtain the desired effect after their survival and colonizing capacity.

\section{Materials and Methods}

To test organism Trichoderma was isolated from soil using Trichoderma selective medium. A total of eight fungicides each at three concentrations 500, 1000 and 1500 ppm, respectively. Three replications were maintained for each concentration. Out of these carbendazim, carboxin, triadimefon and thiophanate methyl are systemic, whereas, chlorothalonil, copper- oxychloride, mancozeb, and wettable sulphur are nonsystemic. Poisoned food technique was followed to evaluate the effect of fungicides on Trichoderma species were tested against in vitro. Observations for radial growth (in $\mathrm{mm}$ ), along with the colony characters were recorded. The data were analyzed by using the square root transformation values in factorial C.R.D.

\section{Results and Discussion}

The data in table 1 showed that all the fungicides significantly reduced the radial growth of $T$. viride except wettable sulphur, mancozeb, copper-oxychloride, chlorothalonil and triadimefon. There was no radial growth of $T$. viride in carbendazim, carboxin, and thiophanate methyl, while maximum growth (85.22 $\mathrm{mm})$ was recorded in wettable sulphur and minimum $(26.88 \mathrm{~mm})$ in chlorothalonil as compared to $(90.00 \mathrm{~mm})$ in control. These finding are in parallel with Sharma et al., (4) who reported that at lower concentration of mancozeb was compatible with $T$. viride. It has been observed that the highest rate of reduction in growth of $T$. viride was noted in case of toxic action of carbendazim where no radial growth was recorded in all the three concentration. Malathi et al., (3) provided proof that Trichoderma isolates did not grow even at concentration as low as 1 and $5 \mathrm{ppm}$ of carbendazim.

The fungi static activity of wettable sulphur was interesting higher in all observations were nearly at par with control.

All the three tested concentrations significantly reduced the radial growth of $T$. viride, being maximum (41.15 $\mathrm{mm})$ in 1500 ppm. The significant interaction component clearly revealed that with increasing concentration of each fungicide, there was a significant reduction in radial growth of $T$. viride, except carbendazim, carboxin, and thiophanate methyl.

The colony of $T$. viride was loose and cottony growth in copper- oxychloride, mancozeb, and wettable sulphur, while oppressed in triadimefon and chlorothalonil. As regard to pigmentation, it is varied from light green to dark green on upper side and dirty white to light yellow on lower side in all the fungicides (Table 2).

The radial growth of $T$. harzianum was significantly reduced in all the fungicides. There was a mark of reduction in the growth of $T$. harzianum with increasing concentration of fungicides. $T$. harzianum showed compatibility with mancozeb followed by wettable sulphur, copper-oxychloride and highest rate of reduction in the growth of $T$. harzianum were noted of carbendazim, carboxin, and thiophanate methyl where no radial growth at all three test concentrations of the fungicide (Table 3). The trend of results was confirmation with Jayaraj and Radhakrishnan (1) who reported that minimum population of $T$. harzianum was recorded at the highest test concentration of $500 \mathrm{ppm}$. The fungi static activity of mancozeb was interesting higher in all observations were nearly at par with control. 
Table.1 Effect of fungicides on radial growth (in mm) of Trichoderma viride

\begin{tabular}{|l|l|l|l|l|l|}
\hline S. N. & Treatments & \multicolumn{3}{|c|}{ Concentration (in ppm) } & Mean \\
\cline { 3 - 6 } & & 500 & 1000 & 1500 & \\
\hline $\mathbf{1}$ & Carbendazim & $00.0(0.70)^{*}$ & $00.0(0.70)^{*}$ & $00.0(0.70)^{*}$ & $00.0(0.70)$ \\
\hline $\mathbf{2}$ & Carboxin & $00.0(0.70)$ & $00.0(0.70)$ & $00.0(0.70)$ & $00.0(0.70)$ \\
\hline $\mathbf{3}$ & Thiophanate methyl & $00.0(0.70)$ & $00.0(0.70)$ & $00.0(0.70)$ & $00.0(0.70)$ \\
\hline $\mathbf{4}$ & Triadimefon & $49.33(7.06)$ & $45.33(6.76)$ & $39.33(6.30)$ & $46.66(6.71)$ \\
\hline $\mathbf{5}$ & Chlorothalonil & $32.66(5.76)$ & $25.33(5.08)$ & $26.66(4.81)$ & $26.88(5.22)$ \\
\hline $\mathbf{6}$ & Copper- oxychloride & $88.66(9.44)$ & $71.33(8.47)$ & $59.33(7.73)$ & $73.10(8.54)$ \\
\hline $\mathbf{7}$ & Mancozeb & $85.33(9.26)$ & $81.33(9.04)$ & $76.66(8.78)$ & $81.10(9.03)$ \\
\hline $\mathbf{8}$ & Wettable sulphur & $88.66(9.44)$ & $84.66(9.23)$ & $82.33(9.10)$ & $85.22(9.26)$ \\
\hline $\mathbf{9}$ & Control & $90.00(9.51)$ & $90.00(9.51)$ & $90.00(9.51)$ & $90.00(9.51)$ \\
\hline Mean & & $48.29(5.84)$ & $42.22(5.58)$ & $41.15(5.37)$ & \\
\hline
\end{tabular}

*Figures in parentheses are Arc sin transformed values

$\mathrm{CD}$ at 5\% I) Fungicides (F) 0.13 II) Concentrations (C) 0.07 III) FXC 0.22

Table. 2 Colony characters and pigmentation of Trichoderma viride in different Fungicides

\begin{tabular}{|l|l|l|l|l|}
\hline S. N. & \multicolumn{1}{|c|}{ Treatments } & \multicolumn{1}{|c|}{ Colony characters } & \multicolumn{2}{|c|}{ Pigmentation } \\
\cline { 4 - 5 } & & & Upper & Lower \\
\hline $\mathbf{1}$ & Carbendazim & NA & NA & NA \\
\hline $\mathbf{2}$ & Carboxin & NA & NA & NA \\
\hline $\mathbf{3}$ & Thiophanate methyl & NA & NA & NA \\
\hline $\mathbf{4}$ & Triadimefon & Oppressed & Light brown & Light yellow \\
\hline $\mathbf{5}$ & Chlorothalonil & oppressed & & Light yellow \\
\hline $\mathbf{6}$ & Copper- oxychloride & Loose \& Cottony & Light green & Light yellow \\
\hline $\mathbf{7}$ & Mancozeb & Loose \& Cottony & Light green & Dirty white \\
\hline $\mathbf{8}$ & Wettable sulphure & Loose \& Cottony & Light green & Light brown \\
\hline $\mathbf{9}$ & Control & Loose \& Cottony & Light green & Light yellow \\
\hline
\end{tabular}

Table.3 Effect of fungicides on radial growth (in mm) of Trichoderma harzianum

\begin{tabular}{|l|l|l|l|l|l|}
\hline S. N. & Treatments & \multicolumn{3}{|c|}{ Concentration (in ppm) } & Mean \\
\cline { 3 - 6 } & & 500 & 1000 & 1500 & \\
\hline $\mathbf{1}$ & Carbendazim & $00.0(0.70)^{*}$ & $00.0(0.70)^{*}$ & $00.0(0.70)^{*}$ & $00.0(0.70)$ \\
\hline $\mathbf{2}$ & Carboxin & $00.0(0.70)$ & $00.0(0.70)$ & $00.0(0.70)$ & $00.0(0.70)$ \\
\hline $\mathbf{3}$ & Thiophanate methyl & $00.0(0.70)$ & $00.0(0.70)$ & $00.0(0.70)$ & $00.0(0.70)$ \\
\hline $\mathbf{4}$ & Triadimefon & $46.66(6.72)$ & $30.66(5.58)$ & $19.33(4.45)$ & $31.55(5.58)$ \\
\hline $\mathbf{5}$ & Chlorothalonil & $39.33(6.31)$ & $34.66(5.93)$ & $24.66(5.01)$ & $32.88(5.75)$ \\
\hline $\mathbf{6}$ & Copper- oxychloride & $87.33(9.37)$ & $69.33(8.35)$ & $57.33(7.60)$ & $73.33(8.44)$ \\
\hline $\mathbf{7}$ & Mancozeb & $89.33(9.47)$ & $87.33(9.37)$ & $62.66(7.95)$ & $79.77(8.93)$ \\
\hline $\mathbf{8}$ & Wettable sulphure & $88.66(9.33)$ & $83.33(9.15)$ & $58.66(7.69)$ & $76.21(8.72)$ \\
\hline $\mathbf{9}$ & Control & $89.33(9.47)$ & $89.33(9.47)$ & $89.33(9.47)$ & $89.33(9.47)$ \\
\hline Mean & & $48.51(5.86)$ & $43.85(5.55)$ & $34.66(4.92)$ & \\
\hline
\end{tabular}

*Figures in parentheses are Arc sin transformed values

$\mathrm{CD}$ at 5\% I) Fungicides (F) 0.06 II) Concentrations (C) 0.03 III) FXC 0.10 
Table.4 Colony characters and pigmentation of Trichoderma harzianum in different fungicides

\begin{tabular}{|l|l|l|l|l|}
\hline S. N. & \multicolumn{1}{|c|}{ Treatments } & \multicolumn{1}{|c|}{ colony characters } & \multicolumn{2}{c|}{ Pigmentation } \\
\cline { 4 - 5 } & & & Upper & Lower \\
\hline $\mathbf{1}$ & Carbendazim & NA & NA & NA \\
\hline $\mathbf{2}$ & Carboxin & NA & NA & NA \\
\hline $\mathbf{3}$ & Thiophanate methyl & NA & NA & NA \\
\hline $\mathbf{4}$ & Triadimefon & Oppressed & dark brown & Light brown \\
\hline $\mathbf{5}$ & Chlorothalonil & oppressed & Dark green & Light yellow \\
\hline $\mathbf{6}$ & Copper- oxychloride & Loose \& Cottony & Light green & Light brown \\
\hline $\mathbf{7}$ & Mancozeb & Loose \& Cottony & Dark brown & Light yellow \\
\hline $\mathbf{8}$ & Wettable sulphure & Loose \& Cottony & darkt green & Light yellow \\
\hline $\mathbf{9}$ & Control & Loose \& Cottony & Light green & Light yellow \\
\hline
\end{tabular}

All the three tested concentrations significantly reduced the radial growth of $T$. harzianum, with maximum growth in 1500 ppm $(34.66 \mathrm{~mm})$. The colony character of $T$. harzianum differed in different fungicides ranging from fluffy (cottony) to oppressed (Table 4). Similarly, pigmentation too ranged from light green (copper-oxychloride) to dark brown mancozeb and triadimefon) and dark green (chlorothalonil and wettable sulfur) on upper side. On lower side, the pigmentation varied from light yellow (mancozeb, chlorothalonil and wettable sulfur) to light brown (triadimefon and copper-oxychloride).

\section{References}

Jayaraj, J. and Radhakrishan, N.V. (1997). Effectof soil drenching of carbendazim on the survival and competitive saprophytic ability of Trichodrma harzianum. Plant Disease Res. 12: 6566.

Kotwal, I., Vyas, S. C., Verma, R.K. and Jain
A.C. (1981). Screening of some new systemic and non-systemic fungicides against four plant pathogens. Pesticides. 15 (10): 24-26.

Malathi, P; Vishwanath, R; Pradmanabhan, P.; Mohanraj, D and Sunder, A.R. (2002). Compatibility of biocontrol agents with fungicides against red rot disease of sugarcane. Sugar Tech. 4: 131-136.

Sharma, D.D; Gupta, V.P. and Chandrashekhar, D.S, (1999). Compatibility of certain bio-control agents with chemical pesticides and fertilizers. Indian J. of Sericulture 38: $155-160$.

Yan, S.H., Wu, S.P., Lu, D.Q., Liq, S.Y. (2001). Effect of triadimefon on competition between Trichoderma harzianum and Fusarium oxysporum in rhizospheric colonization in watermelon. Acta Phytopathology Sinica. 31 (3): 265-270.

\section{How to cite this article:}

Ashish Shrivastava. 2019. Assessment of Compatibility of Trichoderma Species with Different Fungicides in vitro. Int.J.Curr.Microbiol.App.Sci. 8(02): 2619-2622.

doi: https://doi.org/10.20546/ijcmas.2019.802.305 